JURNAL RISET MAHASISWA AKUNTANSI

http://ejournal.unikama.ac.id/index.php/jrma

JRMA, Volume 6, No 2, Oktober 2018

\title{
PENGARUH RETURN ON ASSETS (ROA), DEBT TO EQUITY RATIO(DER), CURRENT RATIO (CR), RETURN ON EQUITY (ROE), PRICE EARNING RATIO (PER), TOTAL ASSETS TURNOVER (TATO), DAN EARNING PER SHARE (EPS) TERHADAP NILAI PERUSAHAAN MANUFAKTUR YANG TERDAFTAR DI BEI TAHUN 2014-2015
}

\author{
Nila Izatun Nafisah \\ e-mail: nafisahnila616@gmail.com \\ Abdul Halim \\ Ati Retna Sari \\ (Program Studi Akuntansi, FakultasEkonomika dan Bisnis, UniversitasKanjuruhan, Malang)
}

\begin{abstract}
ABSTRAK
Penelitian ini bertujuan untuk menguji dan menjelaskan secara parsial dan dominan pengaruh ROA, DER, CR, ROE, PER, TATO dan EPS terhadap Nilai Perusahaan (Tobins'Q). Sampel penelitian ini adalah perusahaan Manufaktur selama dua tahun berturut-turut yaitu 2014 sampai dengan 2015 yang berjumlah 36 perusahaan dengan menggunakan metode purposive sampling. Teknik analisis data menggunakan Analisis Regresi Linier Berganda, yang terdiri dari ROA terhadap nilai perusahaan (Tobins'Q), DER terhadap Tobins' $Q, C R$ terhadap Tobins' $Q, R O E$ terhadap Tobins' $Q$, PER terhadap Tobins' $Q, T A T O$ terhadap Tobins' $Q$, dan EPS terhadap Tobins' $Q$. Hasil analisis menunjukan bahwa $R O A$ berpengaruh posistif dan signifikan terhadap Tobins' $Q, D E R$ berpengaruh ngatif dan signifikan terhadap Tobins' $Q, C R$ berpengaruh positif dan signifukan terhadap Tobins' $Q$, ROE tidak berpengaruh terhadap Tobins' $Q, P E R$ berpengaruh positif dan signifikan terhadap Tobins' $Q$, TATO berpengaruh positif dan signifikan terhadap Tobins' $Q$ dan EPS berpengaruh positif dan signifikan terhadap Tobins'Q. Dan PER variabel yang paling dominan terhadap Tobins'Q.
\end{abstract}

Kata kunci: ROA, DER, CR, ROE, PER, TATO, EPS dan nilai perusahaan (Tobins'Q).

\begin{abstract}
This study aims to test and explain partially and dominantly the influence of ROA, DER, CR, ROE, PER, TATO and EPS on Company Value (Tobins'Q). The sample of this research is manufacturing companies for two consecutive years, namely 2014 to 2015, amounting to 36 companies using purposive sampling method. Data analysis techniques using Multiple Linear Regression Analysis, which consists of ROA on firm value (Tobins' $Q$ ), DER on Tobins' $Q, C R$ on Tobins' $Q, R O E$ on Tobins' $Q, P E R$ on Tobins' $Q, T A T O$ on Tobins' $Q$, and EPS against Tobins' $Q$. The analysis shows that $R O A$ has a positive and significant effect on Tobins' $Q$, $D E R$ has a significant and significant effect on Tobins' $Q, C R$ has a positive and significant effect on Tobins' $Q$, ROE has no effect on Tobins' $Q$, PER has a positive and significant effect on Tobins' $Q$, TATO has a positive and significant effect on Tobins' $Q$ and EPS has a positive and significant effect on Tobins' $Q$. And PER is the most dominant variable against Tobins' $Q$.
\end{abstract}

Keynotes: ROA, DER, CR, ROE, PER, TATO, EPS and Company Value (Tobins'Q). 
Nila Izatun Nafisah, Pengaruh Return On Assets (ROA), Debt To Equity Ratio(DER), Current Ratio (CR), Return On Equity (ROE), Price Earning Ratio (PER), Total Assets Turnover (TATO), Dan Earning Per Share (EPS) Terhadap Nilai Perusahaan Manufaktur Yang Terdaftar Di BEI Tahun 2014-

\section{PENDAHULUAN}

Nilai perusahaan merupakan konsep penting bagi investor, karena merupakan indikator bagi pasar menilai perusahaan secara keseluruhan. Nilai perusahaan adalah harga yang bersedia dibayar oleh calon pembeli apabila perusahaan tersebut dijual. Nilai perusahaan dapat menggambarkan keadaan perusahaan, (Mahendra, 2012). Jadi, nilai perusahaan adalah suatu perusahaan yang dapat dikatan mempunyai nilai yang baik apabila kinerja perusahaan juga baik. Nilai perusahaan juga dilihat dari suatu nilai sahamnya, jika nilai perusahaanya tinggi maka, dapat dikatakan bahwa suatu perusahaan tersebut nilai perusahaanya juga baik, karena tujuan dari perusahaan sendiri adalah meningkatkan nilai perusahaan melalui peningkatan dari kemakmuran pemilik atau pemegang saham.

Nilai perusahaan dapat ditunjukkan dalam laporan keuangan perusahaan khususnya laporan posisi keuangan perusahaan yang berisi informasi keuangan masa lalu dan laporan laba rugi untuk menilai laba perusahaan yang diperoleh dari tahun ke tahun. Sementara dipihak lain ada yang beranggapan bahwa nilai perusahaaan bukan sekedar dari laporan keuangan saja melainkan nilai perusahaaan dinilai berdasarkan nilai sekarang dari aktiva yang dimiliki perusahaan dan nilai investasi perusahaan yang akan dikeluarkan di masa mendatang (Hidayah, 2015). Jadi pada dasarnya nilai perusahaan bukan hanya dilihat dari laporan keuangan, tetapi juga dilihat dari nilai sekarang dari aktiva yang dimiliki perusahaan dan nilai investasi di masa yang akan mendatang, karena jika perusahaan mengetahui nilai sekarang dari aktiva dan nilai masa mendatang maka hasil dari perusahaaakan lebih maksimal sebab perusahaan mengetahui apa yang akan dijalankan untuk masa yang akan datang.

Jadi, nilai perusahaan adalah suatu perusahaan yang dapat dikatan mempunyai nilai yang baik apabila kinerja perusahaan juga baik. Nilai perusahaan juga dilihat dari suatu nilai sahamnya, jika nilai perusahaanya tinggi maka, dapat dikatakan bahwa suatu perusahaan tersebut nilai perusahaanya juga baik, karena tujuan dari perusahaan sendiri adalah meningkatkan nilai perusahaan melalui peningkatan dari kemakmuran pemilik atau pemegang saham. Nilai perusahaan, merupakan pandangan kinerja perusahaan sekaligus cerminan pertumbuhan diperusahaan.

Hasil analisis laporan keuangan juga akan memberikan informasi tentang kelemahan dan kekuatan yang dimiliki perusahaan. Dengan mengetahui kelemahan ini, maka manajemen akan dapat memperbaiki atau menutupi kelemahan tersebut. Kemudian kekuatan perusahaan yang dimiliki perusahaan harus dipertahankan atau bahkan di tingkatkan. Kekuatan ini yang dapat dijadikan modal selanjutnya kedepan. Yang jelas dengan adanya kelemahan dan kekuatan yang dimiliki, maka akan tergambar kinerja manajemen selama ini (Kasmir 2014:91).

Dari hasil penelitian terdahulu pada penelitian yang dilakukan Chotimah (2013) dengan judul Analisis rasio keuangan terhadap return saham dan nilai perusahaan dari hasil penelitian tersebut menunjukan bahwa (CR) tidak berpengaruh signifikan terhadap return saham dan Tobin's $\mathrm{Q}$, (TATO) tidak berpengaruh signifikan terhadap return saham, tetapi berpengaruh terhadap Tobin's $Q,(R O A),(R O E),(P E R)$ berpengaruh signifikan terhadap return saham dan Tobin's Q. Selanjutnya Yulistiana (2010) dengan judul Pengaruh (EPS), (ROA) dan Arus Kas Operasi terhadap Nilai Perusahaan (Pada Perusahaan Yang Terdaftar Di Jakarta Islamic Index tahun 2004-2006). Menyatakan bahwa penelitian ini menunjukan Eraning Per Share (EPS) dan Arus Kas Operasi tidak berpengaruh signifikan terhadap nilai perusahaan, Return On Assets (ROA) berpengaruh signifikan terhadap nilai perusahaan. Haryati, Ayem (2014) Pengaruh ROA, DER, dan EPS Terhadap Nilai Perusahaan. (Study kasus perusahaan food and beverages yang terdaftar di BEI periode tahun 20092011). Bahwa ROA, DER, dan EPS secara simultan semua berpengaruh posistif terhadap nilai perusahaan, sedangkan hasil penelitian ketiga secara parsial tersebut dua variabel yang berpengaruh 
Nila Izatun Nafisah, Pengaruh Return On Assets (ROA), Debt To Equity Ratio(DER), Current Ratio (CR), Return On Equity (ROE), Price Earning Ratio (PER), Total Assets Turnover (TATO), Dan Earning Per Share (EPS) Terhadap Nilai Perusahaan Manufaktur Yang Terdaftar Di BEI Tahun 2014-

posistif signifikan terhadap nilai perusahaan ROA, EPS. Sedangkan DER tidak berpengaruh signifikan terhadap nilai perusahaan.

Dari penelitian yang telah dilakukan sebelumnya masih terdapat perbedaan hasil penelitian menganai rasio keuangan terhadap nilai perusahaan. Pada penelitian ini peneliti telah menambahkan variabel (EPS) karena EPS merupakan rasio mengukur keberhasilan manajemen untuk mencapai keuntungan bagi pemegang saham, apabila rasio yang rendah berarti manajemen belum berhasil untuk memuaskan pemegang saham (Kasmir, 2014). Selain itu berdasarkan penelitian terdahulu menurut Haryati (2014) menyatakan bahwa variabel EPS berpengaruh positif terhadap nilai perusahaan dengan demikian penelitian ini tidak mendukung hasil penelitian Yulistiana (2010) yang menunjukan bahwa EPS tidak berpengaruh terhadap nilai perusahaan. Oleh karena itu, penelitian ini akan melakukan penelitian ulang atas pengaruh rasio keuangan terhadap nilai perusahaan manufaktur yang terdaftar di BEI pada periode 2014-2015. Selanjutnya alasan peneliti memilih perusahaan manufaktur dikarenakan perusahaan manufaktur di Bursa Efek Indonesia yang terdiri dari berbagai sub sektor industri sehingga dapat memberikan reaksi pasar modal keseluruhan, perusahaan manufaktur juga merupakan perusahaan terbanyak di Bursa Efek Indonesia. Dari hasil beberapa peneliti terdahulu dan melihat betapa pentingnya rasio-rasio keuangan, maka penelitian ini dengan tujuan untuk menguji dan menjelaskan secara parsial pengaruh ROA, DER, CR, ROE, PER, TATO dan EPS terhadap Nilai Perusahaan.

\section{TINJAUAN PUSTAKA}

\section{a. Nilai perusahaan}

Nilai perusahaan menurut Harmono (2009) merupakan kinerja perusahaan yang dicerminkan oleh harga saham yang dibentuk oleh permintaan dan penawaran di pasar modal yang merefleksikan penilaian masyarakat terhadap kinerja perusahaan. Semakin tinggi harga saham semakin tinggi pula nilai perusahaan. Sedangkan menurut Nurlela dan Ishaluddin (2008) menjelaskan bahwa enterprise value (EV) atau dikenal juga sebagai firm value (nilai perusahaan) merupakan konsep penting bagi investor, karena merupakan indikator bagi pasar menilai perusahaan secara keseluruhan.

\section{b. Laporan Keuangan}

Seperti diketahui bahwa setiap laporan keuangan dibuat pasti memiliki tujuan tertentu. Dalam praktiknya terdapat beberapa tujuan yang hendak dicapai, terutama bagi pemilik usaha dan manajemen perusahaan. disamping itu tujuan laporan keuangan disusun guna memenuhi kepentingan berbagai pihak yang berkempentingan terhadap perusahaan (Kasmir, 2014). Jadi, dengan memperoleh keuangan suatu perusahaan, maka akan dapat diketahui kondisi keuangan perusahaan secara menyeluruh. Kemudian laporan keuangan tidak hanya sekedar cukup dibaca saja, akan tetapi juga harus dimengertidan dipahami posisi keuangan perusahaan saat ini. Caranya dengan melakukan analisis keuangan melalui berbagai rasio keuangan yang lazim dilakukan.

\section{c. Rasio Keuangan}

Rasio keuangan adalah angka yang diperoleh dari hasil perbandingan dari satu pos laporan keuangan dengan pos lainnya yang mempuyai hubungan yang relevan dan signifikan. Rasio keuangan hanya menyederhanakan informasi yang menggambarkan hubungan antara pos tertentu dengan pos lainnya, dengan kata penyederhanaan ini dapat menilai secara cepat hubungan antara pos tadi dan dapat membandingkannya dengan rasio lain sehingga kita dapat memperoleh informasi dan memberikan penilaian (Harahap, 2011).

\section{d. Return on Assets}

ROA merupakan rasio yang digunakan untuk mengukur kemampuan perusahaan menghasilkan laba bersih berdasarkan tingkat aset yang tertentu. ROA juga sering disebut sebagai ROI (Return On Investment). Rasio yang tinggi menunjukkan efisiensi manajemen aset, yang berarti efisiensi manajemen (Hanafi dan Halim, 2012). Semakin kecil (rendah) rasio ini, semakin kurang baik, demikian pula sebaliknya. 
Nila Izatun Nafisah, Pengaruh Return On Assets (ROA), Debt To Equity Ratio(DER), Current Ratio (CR), Return On Equity (ROE), Price Earning Ratio (PER), Total Assets Turnover (TATO), Dan Earning Per Share (EPS) Terhadap Nilai Perusahaan Manufaktur Yang Terdaftar Di BEI Tahun 2014-

\section{e. Debt To Equity Ratio}

DER merupakan rasio yang digunakan untuk menilai utang dengan ekuitas. Untuk mencari rasio ini dengan cara membandingkan antara seluruh utang, termasuk utang lancar dan seluruh ekuitas. Rasio ini berguna untuk mengetahui jumlah dana yang disediakan peminjam (kreditor) dengan pemilik perusahaan. Dengan kata lain rasio ini untuk mengetahui setiap rupiah modal sendiri yang dijadikan untuk pinjaman uang (Kasmir 2014).

\section{f. Current Ratio}

Rasio lancar atau CR, merupakan rasio untuk mengukur kemampuan perusahaan membayar kewajiban jangka pendek atau utang yang segera jatuh tempo pada saat ditagih secara keseluruhan. Dengan kata lain, seberapa banyak aktiva lancar yang tersedia untuk menutupi kewajiban jangka pendek yang segerah jatuh tempo. Rasio lancar dapat pula diakatan sebagai bentuk untuk mengukur tingkat keamanan (margin of safety) (Kasmir 2014).

\section{g. Return On Equity}

Hasil pengembalian ekuitas atau (ROE) atau rentabilitas modal sendiri merupakan rasio untuk mengukur laba bersih sesudah pajak dengan modal sendiri. Rasio ini menunjukkan efisiensi penggunaan modal sendiri. Semakin tinggi rasio ini, semakin baik. Artinya, posisi pemiik perusahaan makin kuat, demikian pula sebaliknya (Kasmir 2014).

\section{h. Price Earning Ratio}

Menurut Irfan Fahmi (2013), pengertian PER adalah perbandingan antara market price pershare (laba per lembar saham) terhadap kenaikan pertumbuhan laba yang diharapkan juga akan mengalami kenaikan.

\section{i. Total Assets Turnover}

TATO merupakan rasio yang digunakan untuk mengukur perputaran semua aktiva yang dimiliki perusahaan dan mengukur berapa jumlah penjualan yang diperoleh dari tiap rupiah aktiva atau dengan kata lain digunakan untuk menghitung efektivitas penggunaan total aktiva (Kasmir 2014).

j. Earning Per Share

EPS laba per lembar saham atau disebut juga rasio nilai buku, merupakan rasio untuk mengukur keberhasilan manajeman dalam mencapai keuntungan bagi pemegang saham. Rasio yang rendah berarti manajemen belum berhasil untuk memuaskan pemegang saham, sebaliknya dengan rasio yang tinggi maka kesejahteraan pemegang saham meningkat dengan pengertian lain bahwa tingkat pengembalian yang tinggi (Kasmir 2014).

\section{Kerangka Konseptual}

Kerangka konsepual dari penelitian ini dibangun dari teori nilai perusahaan yang mengacu Harmono (2009), teori ROA yang mengacu (Hanafi dan Halim, 2012), teori DER mengacu (Kasmir 2014), teori CR mengacu (Kasmir 2014), teori ROE mengacu (Kasmir 2014), teori PER mengacu Irfan Fahmi (2013), teori TATO mengecu (Kasmir 2014), dan teori EPS mengacu (Kasmir 2014).

Selain dibangun dari teori, kerangka konseptual dibangun dari penelitian terdahulu yang dilakukan. Selanjutnya juga telah dikemukakan penelitian Helmi Fahrizal (2013), Chotimah (2013) dan Stiyarini (2016) menyatakan bahwa (ROA) berpengaruh terhadap nilai perusahaan. Selanjutnya penelitian Chotimah (2013) dan Stiyarini (2016) menyatakan bahwa (DER) berpengaruh terhadap nilai perusahaan. Selanjutnya penelitian Anhar (2015) bahwa CR berpengaruh terhadap nilai perusahaan. penelitian Chotimah (2013) bahwa (ROE) berpengaruh signifikan terhadap nilai perusahaan. Sedangkan penelitian Chotimah (2013) dan Prasetyorini (2013) menyatakan bahwa (PER) berpengaruh terhadap nilai perusahaan. Selanjutnya dalam penelitian Haryati, Ayem (2013) menyatakan bahwa EPS berpengaruh terhadap nilai perusahaan. 
Nila Izatun Nafisah, Pengaruh Return On Assets (ROA), Debt To Equity Ratio(DER), Current Ratio (CR), Return On Equity (ROE), Price Earning Ratio (PER), Total Assets Turnover (TATO), Dan Earning Per Share (EPS) Terhadap Nilai Perusahaan Manufaktur Yang Terdaftar Di BEI Tahun 2014-

\section{Hipotesis Penelitian}

\section{Pengaruh Return On Assets terhadap Nilai Perusahaan}

ROA merupakan rasio yang digunakan untuk mengukur kemampuan perusahaan menghasilkan laba bersih berdasarkan tingkat aset yang tertentu. ROA juga sering disebut sebagai ROI (Return On Investment). Rasio yang tinggi menunjukkan efisiensi manajemen aset, yang berarti efisiensi manajemen (Hanafi dan Halim, 2012). Semakin kecil (rendah) rasio ini, semakin kurang baik, demikian pula sebaliknya. Pernyataan ini diperkuat oleh penelitian Helmi Fahrizal (2013), Chotimah (2013) dan Stiyarini (2016) menyatakan bahwa (ROA) berpengaruh signifikan terhadap nilai perusahaan. Amarjit dan John D. (2012) penelitian ini sependapat dengan pernyataan tersebut menyatakan bahwa (ROA) berpengaruh positif signifikan terhadap nilai perusahaan. Dengan demikian, dapat ditentukan suatu hipotesis sebagai berikut:

\section{H1: Return On Assets berpengaruh terhadap nilai perusahaan}

\section{Pengaruh Debt To Equity Ratio terhadap Nilai Perusahaan}

DER merupakan rasio yang digunakan untuk menilai utang dengan ekuitas. Untuk mencari rasio ini dengan cara membandingkan antara seluruh utang, termasuk utang lancar dan seluruh ekuitas. Rasio ini berguna untuk mengetahui jumlah dana yang disediakan peminjam (kreditor) dengan pemilik perusahaan. Dengan kata lain rasio ini untuk mengetahui setiap rupiah modal sendiri yang dijadikan untuk pinjaman uang (Kasmir 2014). Pernyataan ini diperkuat oleh Chotimah (2013) dan Stiyarini (2016 ) menyatakan bahwa (DER) berpengaruh signifikan terhadap nilai perusahaan, sedangkan penelitian Haryati, Ayem (2014) dan Anhar (2015) bertolak belakang dengan pernyataan tersebut, Haryati, Ayem dan Anhar menyebutkan bahwa DER tidak berpengaruh signifikan terhadap nilai perusahaan. Dengan demikian, dapat ditentukan suatu hipotesis sebagai berikut:

\section{$\mathrm{H}_{2}$ :Debt To Equity Ratio berpengaruh terhadap nilai perusahaan}

\section{Pengaruh Current Ratio terhadap nilai perusahaan}

Rasio lancar atau CR, merupakan rasio untuk mengukur kemampuan perusahaan membayar kewajiban jangka pendek atau utang yang segera jatuh tempo pada saat ditagih secara keseluruhan. Dengan kata lain, seberapa banyak aktiva lancar yang tersedia untuk menutupi kewajiban jangka pendek yang segerah jatuh tempo. Rasio lancar dapat pula diakatan sebagai bentuk untuk mengukur tingkat keamanan (margin of safety) (Kasmir 2014). Pernyataan tersebut diperkuat dalam penelitian Anhar (2015) bahwa CR berpengaruh signifikan terhadap nilai perusahaan, sedangkan penelitian Stiyarini (2016) bertolak belakang dengan pernyataan tersebut menyatakan bahwa (CR) berpengaruh tidak terhadap nilai perusahaan, dan menurut Chotimah (2013) menyatakan bah CR tidak berpengaruh signifikan terhadap nilai perusahaan. Dengan demikian, dapat ditentukan suatu hipotesis sebagai berikut:

\section{$\mathrm{H}_{3:}$ Current Ratio berpengaruh terhadap nilai perusahaan}

\section{Pengaruh Return On Equity terhadap nilai perusahaan}

Hasil pengembalian ekuitas atau (ROE) atau rentabilitas modal sendiri merupakan rasio untuk mengukur laba bersih sesudah pajak dengan modal sendiri. Rasio ini menunjukkan efisiensi penggunaan modal sendiri. Semakin tinggi rasio ini, semakin baik. Artinya, posisi pemiik perusahaan makin kuat, demikian pula sebaliknya (Kasmir 2014). Pernyataan tersebut diperkuat dalam penelitian Chotimah (2013) bahwa (ROE) berpengaruh signifikan terhadap nilai perusahaan. Sedangkan penelitian Syafira dan hurul (2012) bertolak belakang dengan pernyataan tersebut menyatakan bahwa (ROE) tidak berpengaruh terhadap nilai perusahaan. Dengan demikian, dapat ditentukan suatu hipotesis sebagai berikut: 
Nila Izatun Nafisah, Pengaruh Return On Assets (ROA), Debt To Equity Ratio(DER), Current Ratio (CR), Return On Equity (ROE), Price Earning Ratio (PER), Total Assets Turnover (TATO), Dan Earning Per Share (EPS) Terhadap Nilai Perusahaan Manufaktur Yang Terdaftar Di BEI Tahun 2014-

\section{$\mathrm{H}_{4:}$ Return On Equity berpengaruh terhadap nilai perusahaan}

\section{Pengaruh Price Earning Ratio terhadap nilai perusahaan}

Menurut Irfan Fahmi (2013), pengertian PER adalah perbandingan antara market price pershare (laba per lembar saham) terhadap kenaikan pertumbuhan laba yang diharapkan juga akan mengalami kenaikan. Pernyataan tersebut diperkuat dalam penelitian Chotimah (2013) dan Prasetyorini (2013) menyatakan bahwa (PER) berpengaruh signifikan terhadap nilai perusahaan Dengan demikian, dapat ditentukan suatu hipotesis sebagai berikut:

\section{$\mathrm{H}_{5:}$ Price Price Earning Ratio berpengaruh terhadap nilai perusahaan.}

\section{Pengaruh Total Assets Turnover terhadap nilai perusahaan}

TATO merupakan rasio yang digunakan untuk mengukur perputaran semua aktiva yang dimiliki perusahaan dan mengukur berapa jumlah penjualan yang diperoleh dari tiap rupiah aktiva atau dengan kata lain digunakan untuk menghitung efektivitas penggunaan total aktiva (Kasmir 2014). Pernyataan tersebut diperkuat dalam penelitian Chotimah (2013) menyatakan bahwa TATO berpengaruh signifikan terhadap nilai perusahaan. penelitian ini bertolak belakang dengan penelitian Stiyarini (2016) yang menyatakan bahwa TATO berpengaruh tidak signifikan terhadap niali perusahaan. Dengan demikian, dapat ditentukan suatu hipotesis sebagai berikut:

$\mathrm{H}_{6}$ :Total Assets Turnover berpengaruh terhadap nilai perusahaan

7. Pengaruh Earning Per Share terhadap nilai perusahaan

EPS laba per lembar saham atau disebut juga rasio nilai buku, merupakan rasio untuk mengukur keberhasilan manajeman dalam mencapai keuntungan bagi pemegang saham. Rasio yang rendah berarti

manajemen belum berhasil untuk memuaskan pemegang saham, sebaliknya dengan rasio yang tinggi maka kesejahteraan pemegang saham meningkat dengan pengertian lain bahwa tingkat pengembalian yang tinggi (Kasmir 2014). Pernyataan tersebut diperkuat dalam penelitian Haryati, Ayem (2013) menyatakan bahwa EPS berpengaruh signifikan terhadap nilai perusahaan, sedangakan pendapat Yulistiana (2010) dan bertolak belakang dengan pernyataan tersebut Yulistiana dan menyatakan bahwa EPS tidak berpengaruh signifikan terhadap nilai perusahaan. Dengan demikian, dapat ditentukan suatu hipotesis sebagai berikut:

H7:Earning Per Share berpengaruh terhadap nilai perusahaan 
Nila Izatun Nafisah, Pengaruh Return On Assets (ROA), Debt To Equity Ratio(DER), Current Ratio (CR), Return On Equity (ROE), Price Earning Ratio (PER), Total Assets Turnover (TATO), Dan Earning Per Share (EPS) Terhadap Nilai Perusahaan Manufaktur Yang Terdaftar Di BEI Tahun 2014-

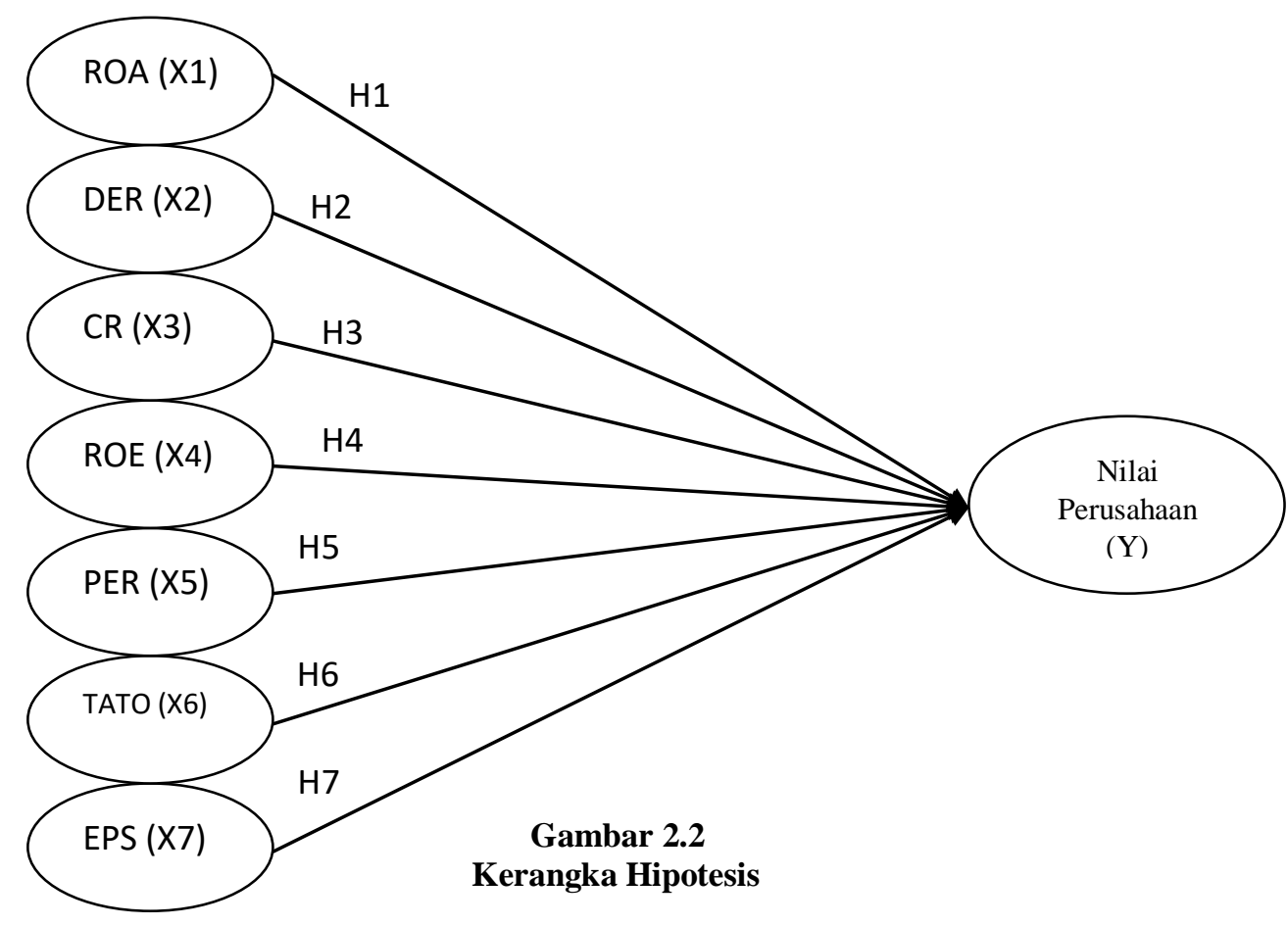

Keterangan :

= Pengaruh Parsial

\section{MOTODE PENELITIAN}

Jenis data yang digunakan dalam penelitian ini adalah data sekunder berupa laporan keuangan perusahaan Manufaktur tahun 2014-2015 dan data harga saham pada tahun 2014-2015, yang diperoleh dari situs BEI yang di akses melalui www.idx.co.id. metode pengumpulan data digunakan dengan teknik dokumentasi yang didasarkan pada laporan keuangan tahunan perusahaan Manufaktur periode 2014-2015 dan data harga saham pada tahun 2014-2015 yang dipublikasikan oleh BEI yang dapat di akses melalui www.idx.co.id.

Populasi yang digunakan dalam penelitian ini adalah seluruh perusahaan manufaktur yang tedaftar di BEI dari tahun 2014-2015 sebanyak 143 perusahaan. penentuan jumlah sampel menagcu pada (Arikunto,2006), jika populasi lebih dari 100, maka dapat diambil antara $10-15 \%$ atau $20-25 \%$. Pada penelitian ini menggunakan

data perusahaan manufaktur yang terdaftar di BEI sebanyak 143 perusahaan. Sehingga jumlah sampel yang digunakan dalam penelitian ini adalah 36 perusahaan.

Metode yang digunakan untuk menarik sampel dalam penelitian ini adalah dengan cara random sampling yaitu pengambilan sampel dari populasi yang dilakukan secara acak tanpa memperhatikan strata yang ada dalam populasi itu, yaitu mengacu pada Arikunto (2006).

\section{Definisi Operasional Variabel}

Adapun definisi operasional variabel yang digunakan dalam penelitian ini adalah sebagai berikut:

\section{Variabel Dependen}

Menurut Smithers dan Wright (2007) menyebutkan bahwa nilai perusahaan dihitung melalui Tobins $Q$, yang diformulasikan (dengan satuan persentase) : 
Nila Izatun Nafisah, Pengaruh Return On Assets (ROA), Debt To Equity Ratio(DER), Current Ratio (CR), Return On Equity (ROE), Price Earning Ratio (PER), Total Assets Turnover (TATO), Dan Earning Per Share (EPS) Terhadap Nilai Perusahaan Manufaktur Yang Terdaftar Di BEI Tahun 2014-

Dimana :

$$
\frac{\{(\text { CP X Jumlah Saham yang Beredar })+\mathrm{TL}+\mathrm{I})\}-\mathrm{CA}}{\mathrm{TA}}
$$

(Tobins $Q=$ Nilai perusahaan $)(\mathrm{CP}=$ Closing Price $)(\mathrm{TL}=$ Total Liabilities $)(\mathrm{I}=$ Inventory $)(\mathrm{CA}=$ Current Assets) $(\mathrm{TA}=$ Total Assets).

\section{Variabel independen}

Variabel independen yang digunakan dalam penelitian ini adalah $\mathrm{CR}$, TATO, DER, ROA, ROE, PER dan EPS. Disimbolkan dengan $\left(X_{1}\right)=$ ROA $\left(X_{2}\right)=$ DER $\left(X_{3}\right)=C R\left(X_{4}\right)=\operatorname{ROE}\left(X_{5}\right)=$ PER $\left(\mathrm{X}_{6}\right)=\mathrm{TATO}\left(\mathrm{X}_{7}\right)=\mathrm{EPS}$

a. Return On Asset (ROA)

Merupakan rasio yang digunakan untuk mengukur kemampuan perusahaan menghasilkan laba bersih berdasarkan tingkat aset yang tertentu.

$$
\begin{aligned}
& \text { ROA }=\frac{\text { laba bersih }}{\text { total asset }} \\
& \text { Sumber : (Hanafi dan Halim, 2012) }
\end{aligned}
$$

\section{b. Debt to Equity Ratio (DER)}

DER merupakan rasio yang digunakan untuk menilai utang dengan ekuitas. Untuk mencari rasio ini dengan cara membandingkan antara seluruh utang, termasuk utang lancar dan seluruh ekuitas.

$$
\begin{aligned}
& \text { DER }=\frac{\text { total utang }}{\text { total equitas }} \\
& \text { Sumber: (Kasmir 2014) }
\end{aligned}
$$

\section{c. Current Ratio (CR)}

Rasio lancar atau CR, merupakan rasio untuk mengukur kemampuan perusahaan membayar kewajiban jangka pendek atau utang yang segera jatuh tempo pada saat ditagih secara keseluruhan.

$$
\mathrm{CR}=\frac{\text { aktiva lancar }}{\text { utang lancar }}
$$

Sumber: (Kasmir 2014)

\section{d. Return On Equity (ROE)}

Hasil pengembalian ekuitas atau (ROE) atau rentabilitas modal sendiri merupakan rasio untuk mengukur laba bersih sesudah pajak dengan modal sendiri.

\section{e. Price Earning Ratio (PER)}

$$
\text { ROE }=\frac{\text { laba bersih sesudah pajak }}{\text { modal }}
$$

Sumber: (Kasmir 2014)

Menurut Irfan Fahmi (2013), pengertian PER adalah perbandingan antara market price pershare (laba per lembar saham) terhadap kenaikan pertumbuhan laba yang diharapkan juga akan mengalami kenaikan.

$$
\begin{aligned}
& \text { PER }=\frac{\text { harga saham }}{\text { laba perlembar saham }} \\
& \text { Sumber : Brigham dan Houson (2010) }
\end{aligned}
$$

\section{f. Total Assets Turnover (TATO)}

TATO merupakan rasio yang digunakan untuk mengukur perputaran semua aktiva yang dimiliki perusahaan dan mengukur berapa jumlah penjualan yang diperoleh dari tiap rupiah aktiva atau dengan kata lain digunakan untuk menghitung efektivitas penggunaan total aktiva.

$$
\text { TATO }=\frac{\text { penjualan }}{\text { total aktiva }}
$$


Nila Izatun Nafisah, Pengaruh Return On Assets (ROA), Debt To Equity Ratio(DER), Current Ratio (CR), Return On Equity (ROE), Price Earning Ratio (PER), Total Assets Turnover (TATO), Dan Earning Per Share (EPS) Terhadap Nilai Perusahaan Manufaktur Yang Terdaftar Di BEI Tahun 2014-

Sumber : Kasmir (2014)

\section{g. Earning Per Share (EPS)}

EPS laba per lembar saham atau disebut juga rasio nilai buku, merupakan rasio untuk mengukur keberhasilan manajeman dalam mencapai keuntungan bagi pemegang saham.

$$
\begin{aligned}
& \text { EPS }=\frac{\text { laba bersih }}{\text { jumlah saham beredar }} \\
& \text { Sumber }:(\text { Kasmir 2014). }
\end{aligned}
$$

\section{Teknis analisis data}

Teknis analisis data dalam penelitian ini dengan menggunakan analisis regresi berganda untuk memperoleh gambaran menyeluruh mengenai hubungan antara variabel satu dengan variabel yang lain. Dalam hal ini variabel dependenya adalah Nilai Perusahaan ( $Y$ ) dan variabel independenya $\left(X_{1}\right)=\operatorname{ROA}\left(X_{2}\right)=\operatorname{DER}\left(X_{3}\right)=C R\left(X_{4}\right)=\operatorname{ROE}\left(X_{5}\right)=\operatorname{PER}\left(X_{6}\right)=$ TATO dan $\left(X_{7}\right)=$ EPS.

Untuk mengetahui apakah ada pengaruh dari variabel independen terhadap variabel dependen, dapat digunakan model regresi linier berganda sebagai berikut $Y=\beta_{0}+\beta_{1} X_{1}+\beta_{2} X_{2}+\beta_{3} X_{3}+\beta_{4} X_{4}+\beta_{5} X_{5}+\beta_{6} X_{6}+\beta_{7} X_{7}+e$

Keterangan:

1. $\mathrm{Y}=$ Nilai perusahan

2. $\beta_{0}=$ Konstanta

3. $\quad \beta_{1}-\beta_{7}=$ Koefisien regresi dari setiap variabel dependen

4. $\mathrm{X}_{1}=$ Ratio On Assets (ROA)

5. $\mathrm{X}_{2}=$ Debt To Equity Ratio (DER)

6. $\mathrm{X}_{3}=$ Return On Equity (ROE)

7. $\mathrm{X}_{4}=$ Curent Ratio $(\mathrm{CR})$

8. $\mathrm{X}_{5}=$ Price Earning Ratio (PER)

9. $\mathrm{X}_{6}=$ Total Assets Turnover (TATO)

10. $\mathrm{X}_{7}=$ Earning Per Share (EPS)

11. $\mathrm{e}=$ Kesalahan pengganggu $($ Eror Term)

Dalam menggunakan alat analisis regresi, perlu dilakukan pengujian asumsi klasik, agar hasil dari analisis regresi ini menunjukkan hubungan yang valid.

\section{A. Uji multikolinieritas}

Uji multikolinieritas dilakukan untuk mengetahui ada tidaknya penyimpangan asumsi multikolinieritas, yaitu adanya hubungan linear antara variabel independen dalam model regresi. Masalah multikolinieritas akan menyebabkan kesulitan dalam melihat pengaruh variabel independen dengan variabel dependen. Adanya gejala multikolineritas bisa dilihat dari tolerance value atau Variance Inflation Factor (VIF). Apabila VIF kurang dari 10 maka tidak terjadi multikolinieritas, tetapi apabila VIF lebih dari 10 maka terjadi multikolinieritas (Sunyoto 2011).

\section{B. Uji Autokorelasi}

Uji autokorelasi bertujuan untuk mengetahui ada tidaknya korelasi antara variabel pengganggu pada periode tertentu dengan variabel pengganggu periode sebelumnya. Autokorelasi muncul karena observasi yang berurutan sepanjang waktu berkaitan satu sama lain. Masalah ini timbul karena residual tidak bebas dari suatu pengamatan ke pengamatan lainnya. Model regresi yang baik adalah regresi yang bebas dari autokorelasi.

Uji autokorelasi dapat dilakukan dengan menggunakan uji Durbin-Watson, dimana hasil pengujian ditentukan berdasarkan nilai Durbin-Watson (Sunyoto 2011). Kriterianya, menurut Firdaus (2010), jika nilai Durbin Watson =1,55-2,46 menunjukkan tidak terjadi autokorelasi. 
Nila Izatun Nafisah, Pengaruh Return On Assets (ROA), Debt To Equity Ratio(DER), Current Ratio (CR), Return On Equity (ROE), Price Earning Ratio (PER), Total Assets Turnover (TATO), Dan Earning Per Share (EPS) Terhadap Nilai Perusahaan Manufaktur Yang Terdaftar Di BEI Tahun 2014-

\section{Uji Heterokedaktisitas}

Menurut Ghozali (2011) uji ini dilakukan untuk mengetahui apakah dalam model regresi terjadi ketidaksamaan variance dari residual satu pengamatan ke pengamatan yang lain. Model yang baik seharusnya

tidak terjadi heteroskedastisitas, yaitu variance dari residual satu pengamatan ke pengamatan yang lain berbeda. Untuk mengetahui adanya heteroskedastisitas dapat dilihat melalui pendekatan scatter plot antara nilai prediksi variabel terikat dengan residualnya.

\section{Uji Normalitas Data}

Menurut Ghozali (2011), uji normalitas bertujuan untuk menguji apakah dalam model regresi, variabel pengganggu atau residual memiliki distribusi normal, bila asumsi ini dilanggar maka uji statistik menjadi tidak valid untuk jumlah sampel kecil. Uji normalitas data dilakukan dengan uji Kolmogorov-Smirnov. Untuk mempermudah dalam melakukan penghitungan secara statistik, analisis yang dilakukan dalam penelitian ini akan diolah dengan bantuan software statistik SPSS versi 23. Suatu data dinyatakan berdistribusi normal jika nilai Asymp Sig (2-tailed) hasil perhitungan Kolmogorov-Smirnov lebih besar dari 0.05 atau 5\%.

Pengujian hipotesis penelitian ini mengguanakan regresi linier berganda. Pengujian ini bertujuan untuk menguji apakah variabel dependen yaitu nilai perusahaan berpengaruh terhadap variabel independen yaitu ROA, DER, CR, ROE, PER, TATO, dan EPS untuk uji hipotesis digunakan uji sebagai berikut:

\section{Uji Statistik $t$}

Uji statistik t dilakukan untuk menunjukkan seberapa jauh pengaruh satu variabel independen secara individual dalam menerangkan variasi variabel dependen (Kusumadilaga, 2010). Jika, nilai sign uji-t menunjukan lebih kecil dari alpha 5\% maka hipotesis pertama, kedua, ketiga, keempat, kelima, dan keenam diterima. Namun, jika sebaliknya nilai sign uji-t menunjukan lebih besar dari alpha 5\% maka hipotesis pertama, keuda, ketiga, keempat, kelima, dan keenam ditolak.

\section{HASIL DAN PEMBAHASAN}

\section{Hasil Uji Asumsi Klasik}

Hasil uji multikolinieritas dengan pendekatan VIF (Variance Inflation Factor) disajikan pada lampiran 1. Dari hasil tersebut menunjukkan bahwa nilai VIF variabel $X 1=1,437$, variabel $X 2=1,255$, variabel X3=1,576, variabel $\mathrm{X} 4=1.679$ dan variabel $\mathrm{X} 5=1.495$, variabel $\mathrm{X} 6=1,398$ dan vriabel $\mathrm{X} 7=1,068$ dari ketujuh variabel bebas tersebut lebih kecil 10. Dengan demikian tidak terjadi multikolinieritas.

Hasil Uji Autokorelsi dengan pendekatan durbin-watson, disajikan pada lampiran 1. Uji Autokorelsi dilakukan dengan menghitung nilai durbin-watson, nilai yang digunakan dalam penelitian adalah 1,55-2,46 berarti tidak terjadi autokorelasi. Hasil uji ini menunjukan bahwa nilai Durbin-Watson sebesar 1.982 ini menunjukan bahwa tidak terjadi Autokorelsi.

Hasil uji heteroskedastisitas dengan pendekatan scatter plot disajikan pada lampiran 1. Berdasarkan grafik Scatterplot tersebut terlihat bahwa titik-titik menyebar secara acak serta menyebar baik diatas maupun dibawah angka 0 pada sumbu Y. Dengan demikian dapat disimpulkan bahwa tidak terjadi heterokedaktisitas.

Hasil uji normalitas dengan pendekatan Kolmogorof-Smirnov disajikan pada lampiran 1. Berdasarkan pengujian Kolmogorov-Smirnov pada tabel tersebut, didapatkan nilai signifikan 
Nila Izatun Nafisah, Pengaruh Return On Assets (ROA), Debt To Equity Ratio(DER), Current Ratio (CR), Return On Equity (ROE), Price Earning Ratio (PER), Total Assets Turnover (TATO), Dan Earning Per Share (EPS) Terhadap Nilai Perusahaan Manufaktur Yang Terdaftar Di BEI Tahun 2014-

sebesar 892, dimana nilai tersebut lebih besar dari pada $\alpha=0,05$, maka dapat disumpulkan bahwa asumsi normalitas residual telah terpenuhi.

\section{Analisis Regresi Linier Berganda}

Analisis regresi linier berganda digunakan untuk mengetahui besarnya ketergantungan pengaruh variabel bebas yaitu nilai perusahaan terhadap variabel dependen yaitu ROA, DER, CE, ROE, PER, TATO, EPS. Maka dapt disususn persamaan regresi linier berganda.

Berikut adalah hasil dari pengujian statistik regresi linier bergandayang dilakukan disajikan pada tabel berikut:

\begin{tabular}{|l|l|l|l|}
\hline \multicolumn{1}{|c|}{ Variabel } & \multicolumn{1}{c|}{ Koefisien regresi } & \multicolumn{1}{c|}{$\begin{array}{c}\text { Nilai signifikan uji } \\
\mathbf{t}\end{array}$} & \multicolumn{1}{|c|}{ Hasil } \\
\hline X1 ROA & 0,341 & 0,000 & Berpengaruh \\
\hline X2 DER & $-0,154$ & 0,000 & Berpengaruh \\
\hline X3 CR & 0,301 & 0,000 & Berpengaruh \\
\hline X4 ROE & 0,202 & 0,367 & Tidak berpengaruh \\
\hline X5 PER & 0,405 & 0,000 & Berpengaruh \\
\hline X6 TATO & 0,313 & 0,000 & Berpengaruh \\
\hline X7 EPS & 0,127 & 0,000 & Berpengaruh \\
\hline $\begin{array}{l}\text { Nilai R-square } \\
=0,635\end{array}$ & & & \\
\hline
\end{tabular}

Sumber: data sekunder diolah peneliti tahun 2016

Berdasarkan tabel tersebut dapat diinterpresatasikan sebagai berikut:

1. Nilai koefisien regresi variabel ROA positif 0,341. Ini menunjukan bahwa variabel ROA berhubungan positif dengan variabel Nilai Persahaan. Artinya jika variabel ROA ditingkatkan satu satuan, maka variabel Nilai Perusahaan kan naik 0,341 satuan. Asumsi variabel lainya tidak berubah.

2. Nilai koefisien regresi variabel DER negatif -0,154. Ini menunjukan bahwa variabel DER berhubungan negatif dengan variabel Nilai Persahaan. Artinya jika variabel DER ditingkatkan satu satuan, maka variabel Nilai Perusahaan kan naik -0,154 satuan. Asumsi variabel lainya tidak berubah.

3. Nilai koefisien regresi variabel $C R$ positif 0,301. Ini menunjukan bahwa variabel $C R$ berhubungan positif dengan variabel Nilai Persahaan. Artinya jika variabel CRditingkatkan satu satuan, maka variabel Nilai Perusahaan kan naik 0,307 satuan. Asumsi variabel lainya tidak berubah.

4. Nilai koefisien regresi variabel ROE positif 0,202. Ini menunjukan bahwa variabel ROE berhubungan positif dengan variabel Nilai Persahaan. Artinya jika variabel ROE ditingkatkan satu satuan, maka variabel Nilai Perusahaan kan naik 0,202 satuan. Asumsi variabel lainya tidak berubah.

5. Nilai koefisien regresi variabel PER positif 0,405. Ini menunjukan bahwa variabel PER berhubungan positif dengan variabel Nilai Persahaan. Artinya jika variabel PER ditingkatkan satu satuan, maka variabel Nilai Perusahaan kan naik 0,405 satuan. Asumsi variabel lainya tidak berubah.

6. Nilai koefisien regresi variabel TATO positif 0,313. Ini menunjukan bahwa variabel TATO berhubungan positif dengan variabel Nilai Persahaan. Artinya jika variabel TATO ditingkatkan satu satuan, maka variabel Nilai Perusahaan kan naik 0,313 satuan. Asumsi variabel lainya tidak berubah.

7. Nilai koefisien regresi variabel EPS positif 0,127. Ini menunjukan bahwa variabel EPS berhubungan positif dengan variabel Nilai Persahaan. Artinya jika variabel EPS ditingkatkan 
Nila Izatun Nafisah, Pengaruh Return On Assets (ROA), Debt To Equity Ratio(DER), Current Ratio (CR), Return On Equity (ROE), Price Earning Ratio (PER), Total Assets Turnover (TATO), Dan Earning Per Share (EPS) Terhadap Nilai Perusahaan Manufaktur Yang Terdaftar Di BEI Tahun 2014-

2015

satu satuan, maka variabel Nilai Perusahaan kan naik 0,127 satuan. Asumsi variabel lainya tidak berubah.

8. Nilai $R$ square 0,635 , menunjukan bahwa perubahan variabel nilai perusahaan $63,5 \%$ dipengaruhi oleh ROA, DER, CR, PER, TATO, dan EPS. Sisanya sebesar 63,5\% di pengaruhi oleh variabel lainya.

\section{Hasil Uji Hipotesis}

1. Hasil Uji Hipotesis Pertama

Nilai signifikan variabel ROA 0,00 lebih kecil 0,05 (alpa 5\%). Ini berarti bahwa variabel ROA secara parsial berpengaruh terhadap nilai perusahaan. Jadi Hipotesis pertama yang menyatakan bahwa ROA secara parsial berpengaruh terhadap Nilai Perusahaan. Diterima

2. Hasil Uji Hipotesis Kedua

Nilai signifikan variabel DER 0,00 lebih kecil 0,05 (alpa 5\%). Ini berarti bahwa variabel DER secara parsial berpengaruh terhadap Nilai Perusahaan. Jadi pada hipotesis kedua ini menyatakan bahwa DER secara parsial berpengaruh terhadap Nilai Perusahaan. Diterima

3. Hasil Uji Hipotesis Ketiga

Nilai signifikan variabel CR 0,00 lebih kecil 0,05 (alpa 5\%). Ini dapat dikatakn berarti variabel CR secara parsial berpengaruh terhadap Nilai Perusahaan. Jadi pada hipotesis ketiga tersebut dapat dinyatakan bahwa CR secara parsial berpengaruh terhadap Nilai Perusahaan. Diterima

4. Hasil Uji Hipotesis Keempat

Nilai signifikan variabel ROE 0,367 lebih besar 0,05 (alpa 5\%). Ini bahwa variabel ROE secara parsial tidak berpengaruh terhadap Nilai Perusahaan. Jadi hipoteisis keempat yang menyatakan bahwa ROE secara parsial tidak berpengaruh terhadap Nilai Perusahaan. Ditolak

5. Hasil Uji Hipotesis Kelima

Nilai signifikan variabel PER 0,00 lebih kecil 0,05 (alpa 5\%). Ini bahwa variabel PER secara parsial berpengaruh terhadap Nilai Perusahaan. Jadi hipotesis kelima yang menyatakan bahwa PER secara parsial berpengaruh terhadap Nilai Persuahaan. Diterima

6. Hasil Uji Hipotesis Keenam

Nilai signifikan variabel TATO 0,00 lebih kecil 0,05 (alpa 5\%). Ini bahwa variabel TATO secara parsial berpengaruh terhadap Nilai Perusahaan. Jadi hipotesis keenam yang menyatakan bahwa TATO secara parsial berpengaruh terhadap Nilai Persuahaan. Diterima

7. Hasil Uji hipotesis Ketujuh

Nilai signifikan variabel EPS 0,00 lebih kecil 0,05 (alpa 5\%). Ini bahwa variabel PER secara parsial berpengaruh terhadap Nilai Perusahaan. Jadi hipotesis ketujuh yang menyatakan bahwa EPS secara parsial berpengaruh terhadap Nilai Persuahaan. Diterima

\section{PEMBAHASAN}

1. Pembahasan pengaruh Return On Assets terhadap Nilai Perusahaan

Hasil penelitian bahwa nilai signifikan variabel sebesar 0.000 lebih kecil dari alpa 0.05 dan nilai koefisien regersi yang sudah distandarisasi sebesar 0.341 bertanda positif. Hal ini menunjukan bahwa ROA berpengaruh positif. Jika variabel ROA dinaikan satu persen, maka variabel nilai perusahaan juga meningkat sebesar 34.1 persen. Hasil penelitian ini mendukung penelitian Farizal (2013), Chotimah (2013), Stiyarini (2016), dan Amarjit (2012). Apabila ROA berpengaruh positif terhadap Nilai Perusahaan, maka ini menunjukan semakin baik suatu kinerja keuangan perusahaan semakin tinggi pula nilai perusahaan dan harga saham. Dapat dikatakan pula jika ROA berpengaruh positif dan signifikan maka dalam pengelolaan dan penggunaan ROA secara efektif dan efisien terbukti mampu meningkatkan nilai perusahaan, karena ROA 
Nila Izatun Nafisah, Pengaruh Return On Assets (ROA), Debt To Equity Ratio(DER), Current Ratio (CR), Return On Equity (ROE), Price Earning Ratio (PER), Total Assets Turnover (TATO), Dan Earning Per Share (EPS) Terhadap Nilai Perusahaan Manufaktur Yang Terdaftar Di BEI Tahun 2014-

merupakan pengukuran kemampuan perusahaan dalam menghasilkan laba bersih berdasarkan tingkat aset tertentu. ROA yang tinggi dapat menunjukan efisiensi manajemen aset. Hasil ini konsisten dengan teori dan pendapat Mogdiliani dan Miller dalam Ulupui (2007:13-14) yang menyatakan bahwa nilai perusahaan ditentukan oleh earnings power dari aset perusahaan. Hasil yang positif menunjukkan bahwa semakin tinggi earnings power semakin efisien perputaran aset dan semakin tinggi profit margin yang diperoleh oleh perusahaan.

\section{Pembahasan pengaruh Debt To Equity Ratio terhadap Nilai Perusahaan}

Hasil penelitian bahwa nilai signifikan variabel sebesar 0.000 lebih kecil dari alpa 0.05 dan nilai koefisien regersi yang sudah distandarisasi sebesar -0.154 bertanda negatif. Hal ini menunjukan bahwa DER berpengaruh negatif. Jika variabel DER dinaikan satu persen, maka variabel nilai perusahaan juga meningkat sebesar -15.4 persen, penelitian ini bertolak belakang dengan Stiyarini (2016) bahwa DER memiliki perngaruh signifikan terhadap nilai perusahaan. Semakin banyaknya hutang, juga dipandang sebagai perusahaan yang yakin dengan prospek perusahaan di masa yang akan datang. Investor menganggap perusahaan yang mempunyai banyak hutang akan mempunyai kesempatan dalam menggunakan modalnya untuk ekspansi atau pengembangan, dengan harapan semakin berkembangnya perusahaan maka keuntungan bagi perusahaan dan investor juga akan semakin naik sehingga investor tertarik untuk membeli saham perusahaan (Kusnaeni, 2012). Dapat disimpulkan bahwa semakin tinggi utang perusahaan, maka semakin turun nilai perusahaan, sehingga DER memiliki pengaruh negatif terhadap nilai perusahaan. Dapat dikatakan pula semakin tinggi rasio DER, maka akan mengakibatkan rendah pula tingkat nilai perusahaan. Disimpulkan bahwa jika rasio DER berpengaruh negatif terhadap nilai perusahaan, maka tingkat untuk nilai perusahaan semakin kecil pula. Maka dari itu dengan tingginya hutang perusahaan, maka akan mempengaruhi rendahnya tingkat nilai perusahaan.

\section{Pembahasan pengaruh Current Ratio terhadap Nilai Perusahaan}

Hasil penelitian bahwa nilai signifikan variabel sebesar 0.000 lebih kecil dari alpa 0.05 dan nilai koefisien regersi yang sudah distandarisasi sebesar 0.301 bertanda positif. Hal ini menunjukan bahwa CR berpengaruh positif. Jika variabel CR dinaikan satu persen, maka variabel nilai perusahaan juga meningkat sebesar 30.1 persen. Hasil penelitian ini mendukung penelitian Anhar (2015). CR berpengaruh postif terhadap nilai perusahaan, hal ini menunjukan bahwa kemampuan membayar utang jangka pendek dapat mempengaruhi nilai perusahaan. Sehingga rasio ini dapat digunakan dalam penggunaan informasi laporan keuangan bagi investor untuk dapat menilai hasil operasi dan kondisi keuangan perusahaan masa kini maupun sebagai pegangan dimasa yang akan datang. Temuan ini mendukung pernyataan Budiarto (2009), yang menyatakan bahwa kemampuan untuk membayar utang lancar dari suatu perushaan diukur kemampuannya untuk memperoleh kas atau kemampuan untuk merubah aset kas menjadi kas. Perusahaan sudah tidak mampu untuk memenuhi kewajiban jangka pendeknya pada tanggal jatuh tempo berarti penilaian terhadap rasio-rasio yang lain dari perusahaan tidak lagi bermanfaat. Maka dapat disimpulkan bahwa apabila kewajiban jangka pendek segera dipenuhi oleh nilai perusahaan, maka akan menghasilkan suatu keamanan untuk nilai perusahaan, sehingga dapat dinyatakan bahwa CR berpengaruh positif terhadap nilai perusahaan. Dengan hasil tingkat likuiditas yang tinggi maka akan dapat memperkecil kegagalan perusahaan dalam memenuhi kewajiban finansial jangka pendek kepada kreditur dan juga sebaliknya. 
Nila Izatun Nafisah, Pengaruh Return On Assets (ROA), Debt To Equity Ratio(DER), Current Ratio (CR), Return On Equity (ROE), Price Earning Ratio (PER), Total Assets Turnover (TATO), Dan Earning Per Share (EPS) Terhadap Nilai Perusahaan Manufaktur Yang Terdaftar Di BEI Tahun 2014-

\section{Pembahasan pengaruh Return On Equity terhadap Nilai Perusahaan}

Hasil penelitian bahwa nilai signifikan variabel sebesar 0.367 lebih kecil dari alpa 0.05 dan nilai koefisien regersi yang sudah distandarisasi sebesar 0.202 bertanda positif. Hal ini menunjukan bahwa ROE

berpengaruh positif. Jika variabel ROE dinaikan satu persen, maka variabel nilai perusahaan juga meningkat sebesar 20.2 persen. Pernyataan ini mendukung dengan penelitian Syafira, Hurul (2012) yang menyatakan bahwa ROE tidak berpengaruh terhadap nilai perusahaan. Penurunan ROE disebabkan karena banyaknya perusahaan yang mengalami kerugian sedangkan jumlah modal sendiri mengalami peningkatan, sehingga menghasilkan nilai ROE yang rendah yang menunjukkan bahwa perusahaan tidak mampu memperoleh laba bagi para pemegang saham Syafira, Hurul (2012). Apabila ROE tidak berpengaruh terhadap nilai perusahaan, maka dapat dikatakan bahwa tingkat kemampuan perusahaan dalam menghasilkan keuntungan dengan modal sendiri rendah. Maka dari itu akan menimbulkan ketidak tertarikan dari seorang investor. ROE tidak berpengaruh terhadap nilai perusahaan karena peningkatan jumlah modal tidak diikuti dengan peningkatakan jumlah laba dalam perusahaan, sehingga akan menunjukan bahwa perusahaan tidak akan mampu memperoleh laba bagi pemegang saham. Dengan hasil tersebut maka akan mempengaruhi investor untuk mengurangi jumlah modal yang akan dinvestasikanyan. Hal tersebut akan mengakibatkan turunya jumlah permintaan terhadap saham perusahaan yang akan mengakibatkan pula harga saham menjadi menurun dan nilai perusahaan akan menjadi rendah. Sebab dengan hasil laba yang rendah maka investor akan memandang hasil yang akan diperoleh juga akan mengalami penurunan.

\section{Pembahasan pengaruh Price Earning Ratio terhadap Nilai Perusahaan}

Hasil penelitian bahwa nilai signifikan variabel sebesar 0.000 lebih kecil dari alpa 0.05 dan nilai koefisien regersi yang sudah distandarisasi sebesar 0.405 bertanda positif. Hal ini menunjukan bahwa PER berpengaruh positif. Jika variabel PER dinaikan satu persen, maka variabel nilai perusahaan juga meningkat sebesar 40.5 persen. Hasil penelitian ini mendukung penelitian Chotimah (2013) dan Prasetyo (2013). Dapat dikatakan bahwa berarti indikator perkembangan atau pertumbuhan suatu perusahaan dimasa yang akan datang. Semakin tinggi suatu rasio PER, semakin tinggi pula pertumbuhan suatu laba yang diharap kan perusahaan dibandingkan dengan laba per lembar saham dan tingkat nilai perusahaan akan meningkat pula. PER dapat dikatakan memiliki hubungan yang positif terhadap nilai perusahaan, maka dapat disimpulkan bahwa jika PER meningkat maka harga saham akan meningkat pula. Dapat dikatakan bahwa jika perusahaan memiliki nilai PER tinggi maka perusahaan tersebut mampu menghasilkan penghasilan laba yang besar. Tingkat pendapatan perusahaan yang bernilai besar maka akan dapat menarik investor untuk berinvestasi di perusahaan tersebut. Semakin tinggi nilai rasio tersebut maka dapat dinyatakan bahwa semakin baik harapan bagi investor tentang perkembangan didalam perusahaan yang akan datang.

\section{Pembahasan pengaruh Total Assets Turnover terhadap Nilai Perusahaan}

Hasil penelitian bahwa nilai signifikan variabel sebesar 0.000 lebih kecil dari alpa 0.05 dan nilai koefisien regersi yang sudah distandarisasi sebesar 0.313 bertanda positif. Hal ini menunjukan bahwa TATO berpengaruh positif . Jika variabel TATO dinaikan satu persen, maka variabel nilai perusahaan juga meningkat sebesar 31.3 persen. Hasil penelitian ini mendukung penelitian Chotimah (2013). Hal ini menunjukkan bahwa analisis rasio keuangan merupakan instrumen analisis perusahaan yang ditujukan untuk menunjukkan perubahan dalam kondisi keuangan perusahaan yang bersangkutan. Dengan analisis rasio keuangan ini dapat diketahui kekuatan dan kelemahan perusahaan dibidang keuangan, rasio aktivitas ini melibatkan perbandingan antara tingkat penjualan 
Nila Izatun Nafisah, Pengaruh Return On Assets (ROA), Debt To Equity Ratio(DER), Current Ratio (CR), Return On Equity (ROE), Price Earning Ratio (PER), Total Assets Turnover (TATO), Dan Earning Per Share (EPS) Terhadap Nilai Perusahaan Manufaktur Yang Terdaftar Di BEI Tahun 2014-

dan investasi pada berbagai jenis aktiva. Rasio-rasio aktivitas menganggap bahwa sebaiknya terdapat keseimbangan yang layak antara penjualan dan berbagai unsur aktiva, yaitu persediaan, piutang, aktiva tetap, serta aktiva lain. Dengan adanya penjualan yang efektif maka akan mempengaruhi tingkat nilai perusahaan, yang dapat menimbulkan tingkatan yang tinggi. Dengan kata lain, bahwa dapat dikatakan prospek yang akan didapatkan akan meningkat pula. Maka dari itu, perusahaan lebih meningkatkan lagi penjualan dengan berbagai cara seperti menarik konsumen untuk membeli dengan cara lebih ditambahkan lagi kualitas produk yang telah dijual kepada konsumen.

\section{Pembahasan pengaruh Earning Per Share terhadap Nilai Perusahaan}

Hasil penelitian bahwa nilai signifikan variabel sebesar 0.000 lebih kecil dari alpa 0.05 dan nilai koefisien regersi yang sudah distandarisasi sebesar 0.127 bertanda positif. Hal ini menunjukan bahwa EPS berpengaruh positif. Jika variabel EPS dinaikan satu persen, maka variabel nilai perusahaan juga meningkat sebesar 12.7 persen. Hasil penelitian ini mendukung penelitian Haryati, Ayem (2013). Maka dapat disimpulkan bahwa untuk mengukur keberhasilan manajemen dalam mencapai keuntungan bagi pemegang saham dan rasio yang dapat menunjukan laba bersih yang berhasil diperoleh perusahaan untuk setiap unit saham selama satu periode tertentu dalam bentuk uang. Nilai EPS yang semakin tinggi akan meningkatkan minat investor untuk berinvestasi. Semakin banyak jumlah investasi yang dilakukan maka perusahaan akan mengalami peningkatan nilai perusahaan. Dengan tingkat rasio yang tinggi, maka kesejahteraan pemegang saham akan meningkat, dengan kata lain bahwa tingkat untuk pengembalian terhadap perusahaan akan tinggi pula. Rasio yang rendah dapat dikatakan bahwa manajemen belum berhasil dalam memuaskan pemegang saham, oleh karena itu jika ingin memberikan tingkat yang tinggi bagi pemegang saham maka untuk rasio EPS harus lebih ditingkatkan lagi, agar ketertarikan bagi investor untuk berinvestasi lebih tinggi.

\section{KESIMPULAN}

Berdasarkan pengujian hasil penelitian dan pembahasan yang telah dilakukan dapat disimpulkan bahwa variabel ROA secara parsial berpengaruh positif terhadap nilai perusahaan. Hal ini ditunjukkan oleh nilai signifikansi lebih 0.000 kecil alpa 0,05. Selanjutnya variabel DER secara parsial berpengaruh negatif terhadap nilai perusahaan. Hal ini ditunjukkan oleh nilai signifikansi lebih 0.000 kecil alpa 0,05. Kemudian variabel CR secara parsial berpengaruh positif terhadap nilai perusahaan. Hal ini ditunjukkan oleh nilai signifikansi lebih 0.000 kecil alpa 0,05. Berikutnya variabel PER secara parsial berpengaruh positif terhadap nilai perusahaan. Hal ini ditunjukkan oleh nilai signifikansi lebih 0.000 kecil alpa 0,05. Selanjutnya variabel TATO secara parsial berpengaruh positif terhadap nilai perusahaan. Hal ini ditunjukkan oleh nilai signifikansi lebih 0.000 kecil alpa 0,05. Dan selanjutnya variabel EPS secara parsial berpengaruh positif terhadap nilai perusahaan. Hal ini ditunjukan oleh nilai signifikan $t$ sebesar 0.000 lebih kecil dari alpa 0.05 . Selanjutnya variabel ROE secara parsial tidak berpengaruh terhadap nilai perusahaan. Hal ini ditunjukan oleh nilai signifikan sebesar 0.345 lebih besar dari alpa 0.05 .

\section{DAFTAR PUSTAKA}

Arikunto, Suharsimi, 2006, Prosedur Penelitian: Suatu Pendekatan Praktek, Edisi Revisi, PT. Rineka Cipta, Jakarta.

Amarjit Gill, Ph.D. DAN John D. Obradovich, Ph.D. 2012. The Impact of Corporate Governance and Financial Leverage on the Value of American Firms. Jurnal Universitas Trident University International. http://www.internationalresearchjournaloffinanceandeconomics.com di akses pada tanggal 01 November 2016 pukul 23:40 
Nila Izatun Nafisah, Pengaruh Return On Assets (ROA), Debt To Equity Ratio(DER), Current Ratio (CR), Return On Equity (ROE), Price Earning Ratio (PER), Total Assets Turnover (TATO), Dan Earning Per Share (EPS) Terhadap Nilai Perusahaan Manufaktur Yang Terdaftar Di BEI Tahun 2014-

Augusty, Ferdinand. 2014. Metode Penelitian Manajemen, Edisi 5. Seri Pustaka Kunci: Diponegoro

Brigham dan Housten. 2010. Dasar-dasar Manajemen Keuangan Buku 1 (Edisi 11). Jakarta : Salemba Empat

Chotimah, Chusnul (2013). Analisis Rasio Keuangan Terhadap Return Saham dan Nilai Perusahaan. Jurnal Sekolah Tinggi Ilmu Ekonomi Indonesia (STIESIA) Surabaya. Sumber : http://ejournal.stiesia.ac.id di akses 19 Oktober 2016 pukul 16:05:50

Fahrizal, Helmy (2013) Pengaruh Retuen On Assets (ROA), Return On Equity (ROE) dan Invesment Opportunity Set (IOS) Terhadap Nilai Perusahaan. Skripsi Universitas Islam Negeri Syarif Hidayatullah Jakarta. Sumber : http://repository.uinjkt.ac.id di akses 02 November 2016 pukul 23:30

Ghozali, Imam, 2011, Aplikasi analisis multivariate dengan program IBM SPSS 19, Edisi Kelima, Universitas Diponegoro, Semarang.

Harmono. 2009. Manajemen Keuangan Berbasis Balanced Scorecard. Edisi Pertama. Cetakan Pertama. Bumi Aksara. Jakarta.

Haryati Winur, dan Sri Ayem2014, Pengaruh Return On Assets, Debt To Equity Ratio, Earning Per Share Terhadap Nilai Perusahaan (study kasus pada perusahaan food and beverages yang terdaftar di BEI periode 2009-2011), Jurnal Akuntansi Universitas Sarjanawiyata Taman Siswa Yogyakarta, Vol.2 , No.1 , Juni 2014.R

Juniarti . 2009. Penggunaan Economic Added (EVA) dan Tobins'Q sebagai alat ukur kinerja finansial perusahaan di industri Food dan Beverages yang listing di Bursa Efek Indonesia . Skripsi S1, Fakultas Ekonomi Universitas Hasanuddin, Makasar.

Horne, James C. Van dan John M Wachowicz, Jr. 2012. Prinsip-Prinsip Manajemen Keuangan (Edisi 13). Jakarta : Salemba Empat

Kasmir, 2014. Pengantar Manajemen Keuangan, Edisi Kedua, Kencana Prenadamedia Group, Jakarta. I.

Karaca dan Arif Safsar 2012 The Effect Of Financial Rations On The Firm Value : Evidence From Turkey. Jurnal University, Tokat, Turkey. diakses tanggal 01 November 2016 pukul 23:30.

Kusumadilaga, Rimba. 2010. Pengaruh Corporate Social Responsibility Terhadap Nilai Perusahaan dengan Profitabilitas Sebagai Variabel Moderating, Skripsi, Fakultas Ekonomi Diponegoro Semarang.

Kusnaeni, D. 2012. Pengaruh Struktur Modal Terhadap Nilai Perusahaan pada Industri Barang Konsumsi di Bursa Efek Indonesia. Disertasi. Program Pasca Sarjana Universitas Terbuka Jakarta.

Meythi. 2013. Rasio Keuangan Terbaik Untuk Memprediksi Nilai Perusahaan, Jurnal Keuangan dan Perbankan, Vol.17, No.2 Mei 2013, hlm. 200-210.

Mahendra. D.A. 2012. Pengaruh Kinerja Keuangan Terhadap Nilai Perusahaan Pada Perusahaan Manufaktur Di Bursa Efek Indonesia, Jurnal Manajemen Strategi Bisnis, dan Kewirausahaan Vol. 6. 131 No. 2 Agustus 2012 : 130-138.

Modigliani, Franco, and Merton H. Miller, 2007, The Cost of Capital, CorporationFinance, and Theory of Investment, American Economic Review.

Prasetyorini, Bhekti Fitri. 2013. Pengaruh Ukuran Perusahaan, Leverage, Price Earning Ratio dan Profitabilitas terhadap Nilai Perusahaan. Jurnal Ilmu Manajemen I Volume 1 
Nila Izatun Nafisah, Pengaruh Return On Assets (ROA), Debt To Equity Ratio(DER), Current Ratio (CR), Return On Equity (ROE), Price Earning Ratio (PER), Total Assets Turnover (TATO), Dan Earning Per Share (EPS) Terhadap Nilai Perusahaan Manufaktur Yang Terdaftar Di BEI Tahun 2014-

Stiyarini (2016). Pengaruh kinerja keuangan terhadap nilai perusahaan pada perusahaan jasa telekomunikasi. Sekolah Tinggi Ilmu Ekonomi Indonesia (STIESIA) Surabaya. Sumber : http://ejournal.stiesia.ac.id di akses 10 Oktober 2016 pukul 06:11:30

Smithers, Adrew dan Stephen Wright.2007. Valluing Wall Street. McGraw Hill

Sunyoto, D. 2011 .Analisis Regresi dan Uji Hipotesis, Yogyakarta : CAPS.

Sugiyono. 2007. Metode Penelitian Bisnis. Cetakan Kesepuluh. Bandung: CV. Alfabeta.

Sutrisno. 2007. Manajemen Keuangan Teori, Konsep, dan Aplikasi. Yogyakarta : EKONISIA.

Harahap, Sofyan Safri. 2011. Analisis Kritis dan Laporan Keuangan. Jakarta : Raja Grafindo Persada.

Syarifa Hariri Hurul Ain, Herlin Tundjung Setijaningsih (2012) Pengaruh Return On Asset (Roa) Return On Equity (Roe) Dan Kepemilikan Manajerial Terhadap Nilai Perusahaan (Studi Empiris Pada Perusahaan Manufaktur Di Bursa Efek Indonesia (Bei) Periode 2009-2011). Jurna.l Universitas Bina Nusantara, Jl. Kebon Jeruk Raya No. 27, Jakarta Barat 11530.

Tetelepta, I. E. (2011). Pengaruh Kinerja Keuangan Terhadap Nilai Perusahaan Pada Perusahaan Manufaktur yang terdaftar Di Bursa Efek Indonesia. Rangkuman Skripsi. Fakultas Ekonomi Sekolah Tinggi Ilmu Ekonomi Perbanas Surabaya.

Yulistiana, Ana. 2010. Pengaruh Earning Per Share (EPS), Return On Asset (ROA), Dan Arus Kas Operasi, Terhadap Nilai Perusahaan (Pada Perusahaan Yang Terdaftar Di Jakarta Islamic Index Tahun 2004-2006). Skripsi Publikasi. UIN Sunan Kalijaga, Yogyakarta. di akses tanggal 28 Oktober 2016 pukul 13:54:04

www.idx.co.id 